\title{
Probiotic Potential of Lactic Acid Starter Cultures Isolated from a Traditional Fermented Sorghum-Millet Beverage
}

\author{
Stellah Byakika, Ivan Muzira Mukisa ${ }^{D}$, Yusuf Byenkya Byaruhanga, and Charles Muyanja \\ Department of Food Technology and Nutrition, School of Food Technology Nutrition and Bioengineering, \\ College of Agricultural and Environmental Sciences, Makerere University, P O Box 7062, Kampala, Uganda
}

Correspondence should be addressed to Ivan Muzira Mukisa; ivanmukisa@gmail.com

Received 26 March 2020; Accepted 10 July 2020; Published 4 August 2020

Academic Editor: Joseph Falkinham

Copyright $(92020$ Stellah Byakika et al. This is an open access article distributed under the Creative Commons Attribution License, which permits unrestricted use, distribution, and reproduction in any medium, provided the original work is properly cited.

The purpose of this study was to establish the probiotic potential of lactic acid bacteria (LAB) starter cultures, Lb. plantarum MNC 21, L. lactis MNC 24, and W. confusa MNC 20, isolated from a traditionally fermented sorghum-millet beverage from Uganda. The cultures were examined for tolerance to acid and bile salts, bile salt hydrolase (BSH) activity, antibiotic susceptibility, biogenic amine production, mucin degradation, hydrophobicity, auto-aggregation, adherence to the ileum, coaggregation, and antimicrobial properties against selected pathogenic species. Lb. rhamnosus yoba 2012, a known probiotic, was the reference. The isolates were tolerant to acid $(\mathrm{pH}=3)$ and bile $(1 \%)$. W. confusa MNC 20 and Lb. plantarum MNC 21 exhibited medium BSH activity (11-15 mm diameter of hydrolysis zone) while L. lactis and Lb. rhamnosus yoba 2012 exhibited low BSH activity $(<10 \mathrm{~mm}$ diameter of hydrolysis zone). All isolates lacked mucolytic activity. Lb. plantarum MNC 21 and W. confusa MNC 20 produced agmatine. The candidate and reference microorganisms were resistant to 10 of 21 and 5 of 21 antibiotics, respectively. The isolates exhibited hydrophobic, auto-aggregation and coaggregation properties. These three properties were exhibited more $(p<0.05)$ by the reference than the potential probiotics. The ability of the potential probiotics to attach onto the goat ileum (7.3-8.0 log cfu/ $\left.\mathrm{cm}^{2}\right)$ was comparable to that of Lb. rhamnosus yoba $2012\left(7.6 \log \mathrm{cfu} / \mathrm{cm}^{2}\right)$. The four LAB inhibited E. coli, S. aureus, and S. enterica to the same extent $(p<0.05)$. The findings indicated potential probiotic activity of the starter cultures. However, further in vivo examination of these isolates is required to confirm their probiotic capabilities.

\section{Introduction}

There is a general global interest in the use of probiotics in food, in feeds, and as supplements to enhance human and animal health. Probiotics are live microorganisms which when administered in adequate amounts confer health benefits to the host [1]. Some of the health benefits include the following: prevention of antibiotic related diarrhea, treatment of irritable bowel syndrome, production of $\mathrm{B}$ vitamins, prolongation of life, production of antioxidants and other geroprotectors, serum cholesterol reduction, prevention of cancers, treatment of Helicobacter pylori, relief from lactose intolerance, and improved immune response, among others [2-10].

The major bacterial probiotics used in functional foods are lactic acid bacteria (LAB) and Bifidobacteria [11]. In fact, majority of probiotic research is based on these two groups, given their association with human health, and generally regarded as safe (GRAS) status [12]. Traditional fermented foods exhibit a rich biodiversity of microorganisms from which probiotic microorganisms can be selected [12, 13]. Indeed, many studies have reported a number of probiotic and potentially probiotic microorganisms from various fermented foods including kule naoto, bryndza cheese, hukati, hidal, dadhi, and dangke [14-20].

Obushera is a traditional fermented sorghum-millet beverage originally from south western Uganda. The beverage is used as a weaning food, thirst quencher, and social drink at gatherings [21]. Traditionally, it is fermented using wild microorganisms, with LAB being among the dominant species involved $[22,23]$. LAB are known to contribute to the flavor profile and safety of fermented foods as well as 
promote health by acting as probiotics [24, 25]. Three LAB isolates from Obushera, Lactobacillus (Lb.) plantarum MNC 21, Lactococcus (L.) lactis MNC 24, and Weissella (W.) confusa MNC 20, possess excellent starter culture properties for the beverage $[23,26]$. These cultures have been piloted for the commercial production of Obushera and have promise for use in related fermented food products. However, hitherto this study, no work had been done to establish whether they possess potential probiotic properties. Having been isolated from a traditional fermented food, the starter cultures could be weak or may lack functionality in the human gastrointestinal tract (GIT).

Guidelines for screening candidate microorganisms for probiotic activity have been developed by the Joint FAO/ WHO Working Group [27] and Ganguly et al. [28]. Byakika et al. [29] recently reviewed these guidelines. In summary, candidate microorganisms should be screened for the following (1) tolerance to gastrointestinal conditions, (2) safety, and (3) probiotic benefit(s). It was upon these guidelines that the probiotic potentials of $L b$. plantarum MNC 21, L. lactis MNC 24, and W. confusa MNC 20 in this study were examined. The reference strain was $L b$. rhamnosus yoba 2012, which is a known probiotic [30,31]. The probiotic activity of these starter cultures could translate into technological applications that improve the safety and functionality of fermented foods as well as overall consumer health.

\section{Materials and Methods}

\subsection{Materials}

2.1.1. Microorganisms. Lb. plantarum MNC 21, L. lactis MNC 24, and $W$. confusa MNC 20 were isolated from Obushera [23]. Lb. rhamnosus yoba 2012 (originally named $L b$. rhamnosus GG) (Yoba for Life Foundation Amsterdam, The Netherlands) was obtained from the Uganda Industrial Research Institute (IURI), Kampala, Uganda. E. coli ATCC 25922, S. aureus ATCC 25923, and S. enterica were obtained from the College of Veterinary Medicine, Animal Resources and BioSecurity (CoVAB), Makerere University. Stock cultures were stored at $-80^{\circ} \mathrm{C}$ in Ringer's solution containing $15 \%$ glycerol. The LAB were independently propagated according to the procedure described by Mukisa [21]. From the stock cultures of Lb. plantarum MNC 21, L. lactis MNC 24, W. confusa MNC 20, and $L b$. rhamnosus yoba $2012,0.1 \mathrm{~mL}$ was delivered into $100 \mathrm{~mL}$ of sterile MRS broth (Laboratorios CONDA, Madrid, Spain) and incubated at $30^{\circ} \mathrm{C}$ for $24 \mathrm{~h}$. For the E. coli ATCC 25922, S. aureus ATCC 25923, and S. enterica, $0.1 \mathrm{~mL}$ of stock cultures was separately inoculated in $100 \mathrm{~mL}$ of sterile brain heart infusion (BHI) broth (Laboratorios CONDA, Madrid, Spain) and incubated at $30^{\circ} \mathrm{C}$ for $24 \mathrm{~h}$. The cells were washed and recovered by centrifugation $(7,500 \mathrm{x} g$ for $10 \mathrm{~min})$. The cell pellets were suspended in $100 \mathrm{~mL}$ of sterile Ringer's solution (Oxoid Ltd, Basingstoke, Hampshire, England) and used for the different screening assays.

2.2. Acid and Bile Salt Tolerance. From the fresh culture suspensions, $1 \mathrm{~mL}$ of each isolate was separately added to
$10 \mathrm{~mL}$ of MRS broth ( $\mathrm{pH}=3.0)$ acidified using concentrated $\mathrm{HCl}$. The broth was incubated at $30^{\circ} \mathrm{C}$ for $3 \mathrm{~h}$ and cell counts were determined at 0 and $3 \mathrm{~h}$ of incubation. Thereafter, $1 \mathrm{~mL}$ of the culture from the acidified broth was transferred into $10 \mathrm{~mL}$ of MRS broth ( $\mathrm{pH}=7.8)$ containing $1 \%(\mathrm{w} / \mathrm{v})$ ox bile (Oxoid Ltd, Basingstoke, Hants, England). The $\mathrm{pH}$ of the broth was adjusted using $1 \mathrm{M} \mathrm{NaOH}$. The broth was incubated at $30^{\circ} \mathrm{C}$ for $9 \mathrm{~h}$. Cell counts were determined at 0 , 3,6 , and $9 \mathrm{~h}$ of incubation by pour-plating selected serial dilutions in MRS agar (Laboratorios CONDA, Madrid, Spain). Plates were incubated at $30^{\circ} \mathrm{C}$ for $48 \mathrm{~h}$. Bile salt hydrolase (BSH) activity was also determined according to the method described by Borah et al. [19] with minor modifications. Briefly, freshly grown cultures were spotted on Bile Esculine Agar (Laboratorios CONDA, Madrid, Spain) plates containing $1 \%$ ox bile. The plates were incubated at $30^{\circ} \mathrm{C}$ for $48 \mathrm{~h}$. Hydrolysis of the bile esculine produced a dark brown coloration on the agar. $\mathrm{BSH}$ activity was categorized based on the diameter of zones of hydrolysis as: low BSH activity (up to $10 \mathrm{~mm}$ ), medium $\mathrm{BSH}$ activity (11-15 $\mathrm{mm})$, and high $\mathrm{BSH}$ activity $(>16 \mathrm{~mm})$ [16].

\subsection{Evaluation of Microbial Safety}

2.3.1. Antibiotic Susceptibility. Susceptibility of the isolates to different antibiotics (Bioanalyse, Ankara, Turkey) was determined using the Kirby-Bauer disk diffusion method as previously described [32]. A total of 21 antibiotics (Table 1) were selected from the different classes of antibiotics presented by Charteris et al. [33]. Using sterile cotton swabs, MRS agar plates were swabbed with culture suspensions grown overnight and standardised to 0.5 McFarland (equivalent to $8 \log \mathrm{cfu} / \mathrm{mL}$ ). After an hour, antibiotic discs were placed on the surface of the inoculated agar and incubated at $30^{\circ} \mathrm{C}$ for $48 \mathrm{~h}$. The inhibition zone diameter was measured in $\mathrm{mm}$. The isolates were categorized as resistant, moderately susceptible, or susceptible to the respective antibiotics based on the study by Charteris et al. [33].

2.3.2. Production of Biogenic Amines. Decarboxylation medium was formulated according to Bridson [34]. The medium contained $3 \mathrm{~g} / \mathrm{L}$ yeast extract (Merck, Darmstadt, Germany), $1 \mathrm{~g} / \mathrm{L}$ glucose, $0.016 \mathrm{~g} / \mathrm{L}$ bromocresol purple, and $5 \mathrm{~g} / \mathrm{L}$ of the corresponding amino acid, all supplied by $\mathrm{BDH}$ Laboratory Supplies, Poole, England. The amino acids used were L-histidine, L-tyrosine, L-lysine, L-phenylalanine, $\mathrm{L}$-arginine, and L-ornithine. The $\mathrm{pH}$ of the media was adjusted to $6.1 \pm 0.2$ using $1 \mathrm{M} \mathrm{NaOH}$. The medium was subsequently autoclaved at $121^{\circ} \mathrm{C}$ for $15 \mathrm{~min}$. Ten milliliters of the sterile medium was separately inoculated with $0.1 \mathrm{~mL}$ of each isolate (Section 2.1.1), and $1 \mathrm{~mL}$ of sterile paraffin was added to the tubes to create anaerobic conditions and avoid false positives. Decarboxylation medium without added amino acids was used as a control. The tubes were incubated at $37^{\circ} \mathrm{C}$ for 5 days. Decarboxylase activity was indicated by a deep purple coloration. 
TABLe 1: Susceptibility of lactic acid bacteria to antibiotics.

\begin{tabular}{|c|c|c|c|c|}
\hline \multirow[b]{2}{*}{ Antibiotic } & \multicolumn{4}{|c|}{ Isolate/antibiotic susceptibility } \\
\hline & $\begin{array}{c}\text { Lactobacillus rhamnosus } \\
\text { yoba } 2012\end{array}$ & $\begin{array}{c}\text { Weissella confusa } \\
\text { MNC } 20\end{array}$ & $\begin{array}{c}\text { Lactobacillus plantarum } \\
\text { MNC } 21\end{array}$ & $\begin{array}{c}\text { Lactococcus lactis MNC } \\
24\end{array}$ \\
\hline Penicillin G, $10 \mu \mathrm{g}$ & $\mathrm{S}$ & $\mathrm{R}$ & $\mathrm{R}$ & $\mathrm{R}$ \\
\hline Ampicillin, $10 \mu \mathrm{g}$ & S & $\mathrm{R}$ & $\mathrm{R}$ & $\mathrm{R}$ \\
\hline Amoxicillin, $25 \mu \mathrm{g}^{* *}$ & $S$ & $S$ & $S$ & S \\
\hline $\begin{array}{l}\text { Amoxicillin clavulanic acid, } \\
30 \mu \mathrm{g}\end{array}$ & $S$ & $S$ & $S$ & $S$ \\
\hline Cephalexin, $30 \mu \mathrm{g}$ & MS* & $\mathrm{S}^{*}$ & $S^{*}$ & MS* \\
\hline Vancomycin, $30 \mu \mathrm{g}$ & $\mathrm{R}$ & $\mathrm{R}$ & $\mathrm{R}$ & $\mathrm{R}$ \\
\hline Ceftriaxone, $30 \mu \mathrm{g}$ & $S$ & $\mathrm{~S}$ & S & $\mathrm{S}$ \\
\hline Gentamicin, $10 \mu \mathrm{g}$ & $\mathrm{S}$ & $\mathrm{R}$ & $\mathrm{R}$ & $\mathrm{R}$ \\
\hline Kanamycin, $30 \mu \mathrm{g}$ & $\mathrm{R}$ & $\mathrm{R}$ & $\mathrm{R}$ & $\mathrm{R}$ \\
\hline Streptomycin, $300 \mu \mathrm{g}^{* *}$ & $\mathrm{~S}^{*}$ & $S^{*}$ & $S^{*}$ & $S^{*}$ \\
\hline Erythromycin, $15 \mu \mathrm{g}$ & $\mathrm{S}$ & S & $\mathrm{S}$ & $\mathrm{S}$ \\
\hline Tetracycline, $30 \mu \mathrm{g}$ & S & $\mathrm{R}$ & $\mathrm{R}$ & $\mathrm{R}$ \\
\hline Chloramphenicol, $30 \mu \mathrm{g}$ & S & S & $S$ & S \\
\hline Ciprofloxacin, $5 \mu \mathrm{g}$ & $\mathrm{S}$ & $\mathrm{R}$ & $\mathrm{R}$ & $\mathrm{R}$ \\
\hline Levofloxacin, $15 \mu \mathrm{g}$ & $S^{*}$ & $S^{*}$ & $\mathrm{~S}^{*}$ & $S^{*}$ \\
\hline Metronidazole, $10 \mu \mathrm{g}^{* *}$ & $\mathrm{R}$ & $\mathrm{R}$ & $\mathrm{R}$ & $\mathrm{R}$ \\
\hline $\begin{array}{l}\text { Sulphamethoxazole- } \\
\text { trimethoprim, } 25 \mu \mathrm{g}\end{array}$ & $\mathrm{R}$ & $\mathrm{R}$ & $\mathrm{R}$ & $\mathrm{R}$ \\
\hline Rifampicin, $5 \mu \mathrm{g}$ & $\mathrm{S}$ & $\mathrm{S}$ & $\mathrm{S}$ & $\mathrm{S}$ \\
\hline Novobiocin, $30 \mu \mathrm{g}$ & $\mathrm{S}^{*}$ & $\mathrm{~S}^{*}$ & $\mathrm{~S}^{*}$ & $\mathrm{~S}^{*}$ \\
\hline Colistin, $10 \mu \mathrm{g}$ & $\mathrm{R}$ & $\mathrm{R}$ & $\mathrm{R}$ & $\mathrm{R}$ \\
\hline Nitrofurantoin, $300 \mu \mathrm{g}$ & $\mathrm{S}$ & $S$ & $\mathrm{~S}$ & $\mathrm{~S}$ \\
\hline
\end{tabular}

R: resistant; MS: moderately susceptible; S: susceptible. ${ }^{*}$ Interpretation based on other antibiotics within the same class. ${ }^{* *}$ Antibiotic concentration used was different from the value indicated by Charteris et al. [33]. Standard antibiotic concentrations were used based on Clinical and Laboratory Standards Institute [32].

2.3.3. Mucin Degradation. To examine mucolytic ability of the isolates, the procedure described by Abe et al. [35] was used with some modifications. Mucin obtained from a fresh goat ileum was used. To obtain the mucin, the ileum of a 6month-old healthy goat was obtained immediately after slaughter from a local abattoir. The ileum was washed in sterile diluent (quarter strength Ringer's solution) to remove ingesta from the mucosal surface and transported to the laboratory in cooled $\left(4^{\circ} \mathrm{C}\right)$ sterile diluent. The ileum was cut open, and the mucin was scrapped off using a microscope glass slide. The mucin was centrifuged at $10,000 \mathrm{x} \mathrm{g}$ for $10 \mathrm{~min}$ to remove epithelial cells and other debris. Thereafter, the supernatant was sterilized by autoclaving at $121^{\circ} \mathrm{C}$ for $15 \mathrm{~min}$ [36]. Mucin sterilized this way does not affect the biological activity of its constituents [37].

To examine the mucolytic ability of the isolates, about 3 $\log \mathrm{cfu} / \mathrm{mL}$ of each culture was separately inoculated in $20 \mathrm{~mL}$ of basal media (BM), BM with $1 \%$ glucose (BDH Laboratory Supplies, Poole, England), and BM with $0.3 \%$ goat mucin. The composition of the BM was $2 \mathrm{~g} / \mathrm{L}$ yeast extract (Merck, Darmstadt, Germany) and $2 \mathrm{~g} / \mathrm{L}$ bacteriological peptone. Cultures were incubated at $37^{\circ} \mathrm{C}$ for $48 \mathrm{~h}$. The cell counts were determined at $0 \mathrm{~h}$ and $48 \mathrm{~h}$ of incubation. Intestinal microorganisms from a stool sample obtained from a healthy adult volunteer were used as a positive control. The microbes from the stool were first enriched by preculturing in sterile brain heart infusion broth (Laboratorios CONDA, Madrid, Spain) at $37^{\circ} \mathrm{C}$ for $24 \mathrm{~h}$. For the negative control, a sterile stool sample (heated at $121^{\circ} \mathrm{C}$ for $20 \mathrm{~min}$ ) was used. Cell counts were determined by pour-plating selected serial dilutions in sterile MRS agar for the LAB and sterile plate count agar (PCA) (Laboratorios CONDA, Madrid, Spain) for the intestinal microbes. Plates were incubated at $30^{\circ} \mathrm{C}$ for $48 \mathrm{~h}$. The contribution of substrate (either mucin or glucose) to cell growth was calculated as follows: net growth in basal media with substrate - net growth in basal media.

\subsection{Evaluation of Potential Probiotic Benefits}

\subsubsection{Indicators for Ileal Adherence}

(1) Hydrophobicity Assay. The hydrophobicity of the LAB was evaluated according to methods described by Tomáška et al. [38] and Borah et al. [19] with slight modifications. In brief, washed cultures grown overnight were suspended in sterile quarter strength Ringer's solution. The absorbance $\left(\mathrm{A}_{0}\right)$ of the cell solution at $600 \mathrm{~nm}$ was adjusted to 1 . From the cell suspension, $6 \mathrm{~mL}$ were transferred into a sterile tube and $2 \mathrm{~mL}$ of pure xylene (BDH Laboratory Supplies, Poole, England) or pure toluene (Aldrich Chemical Co., Inc, Canada) was added. The mixture was incubated at $25^{\circ} \mathrm{C}$ for $10 \mathrm{~min}$ and then thoroughly vortexed for $2 \mathrm{~min}$. The mixture was left to separate into two phases at $25^{\circ} \mathrm{C}$ for $20 \mathrm{~min}$. The aqueous phase was carefully removed, and its absorbance $\left(\mathrm{A}_{1}\right)$ was measured at $600 \mathrm{~nm}$. The percentage hydrophobicity was calculated as $\left(\left(\mathrm{A}_{0}-\mathrm{A}_{1}\right) / \mathrm{A}_{0}\right) \times 100$. 
(2) Auto-Aggregation Assay. Auto-aggregation was determined according to the procedure described by Kos et al. [39]. From a cell culture grown overnight, $4 \mathrm{~mL}$ of the cell suspension $(8 \log \mathrm{cfu} / \mathrm{mL}$ ) was vortexed for $10 \mathrm{~s}$ and incubated at $25^{\circ} \mathrm{C}$ for $24 \mathrm{~h}$. At hourly intervals during the $5 \mathrm{~h}$ incubation period, $0.1 \mathrm{~mL}$ of the upper suspension was added to a tube containing $3.9 \mathrm{~mL}$ of quarter strength ringer's solution and its absorbance read at $600 \mathrm{~nm}$. Percentage auto-aggregation was calculated as $\left(\left(\mathrm{A}_{0}-\mathrm{A}_{1}\right) / \mathrm{A}_{0}\right) \times$ 100 , where $A_{0}$ is the absorbance at $0 \mathrm{~h}$ and $A_{1}$ is the absorbance at 5 or $24 \mathrm{~h}$.

(3) Adhesion of LAB to Goat Ileum. To examine adhesion, the method described by Abbasiliasi et al. [40] was used with some modifications. The goat ileum mentioned in the "mucin degradation" section was used. After it was washed to remove ingesta and delivered to the laboratory, the ileum was cut into several $2.5 \mathrm{~cm} \times 2.5 \mathrm{~cm}$ pieces. The pieces were washed by vigorously vortexing thrice in sterile diluent for $10 \mathrm{~s}$ to dislodge the inherent microorganisms. To determine the residual microbial counts $\left(\mathrm{C}_{1}\right)$ on the ileum pieces after the third stage of vortexing, selected serial dilutions of the washed ileum were pour plated in sterile PCA. Thereafter, the ileum pieces were separately incubated in a $9 \log \mathrm{cfu} / \mathrm{mL}$ cell suspension of candidate $\mathrm{LAB}$ at $37^{\circ} \mathrm{C}$ for $45 \mathrm{~min}$. A negative control consisting of the ileum pieces in sterile diluent were also incubated at the same conditions. Thereafter, the pieces were rinsed with sterile diluent to remove the unattached $\mathrm{LAB}$. To determine the counts $\left(\mathrm{C}_{2}\right)$ of the candidate $\mathrm{LAB}$ that were attached to the ileum, the pieces were vigorously vortexed in sterile diluent for $10 \mathrm{~s}$ to dislodge the microbes. Selected serial dilutions of this diluent were pour plated in sterile PCA, and plates were incubated at $37^{\circ} \mathrm{C}$ for $48 \mathrm{~h}$. To compute the LAB that were attached onto the ileum, the formula $\left(\mathrm{C}_{2}-\mathrm{C}_{1}\right) / 6.25 \mathrm{~cm}^{2}$ was used. The experiment was done in duplicates.

\subsubsection{Pathogen Inhibition}

(1) Coaggregation Assay. Coaggregation was determined following the method described by Kos et al. [39]. From cell cultures grown overnight, $2 \mathrm{~mL}$ of each LAB and $2 \mathrm{ml}$ of a specific pathogen (E. coli ATCC 25922, S. aureus ATCC 25923 , or $S$. enterica) were vortexed together for $10 \mathrm{~s}$. The mixture was incubated at $25^{\circ} \mathrm{C}$ for $5 \mathrm{~h}$. Separate controls containing $4 \mathrm{~mL}$ of each individual $\mathrm{LAB}$ or the pathogen were also included. The absorbance of the mixed cultures $(\mathrm{LAB}+$ pathogen) and single cultures (LAB alone or pathogen alone) were read at $600 \mathrm{~nm}$ in a similar manner as in the auto-aggregation assay. The percentage coaggregation was calculated by $\left(\left(A_{x}+A_{y}\right) / 2-\mathrm{A}(x+y)\right) \div\left(\left(A_{x}+A_{y}\right) / 2\right)$, where $A_{x}=$ absorbance of the LAB alone, $A_{y}=$ absorbance of the pathogenic strain alone, and $\mathrm{A}(x+y)=$ absorbance of the mixture of the LAB and pathogen.

(2) Production of Antimicrobial Compounds. Antimicrobial activity was determined using the agar well diffusion assay as described by Vinderola et al. [41] and Jones et al. [42] with modifications. Briefly, LAB were grown overnight in MRS broth (CONDA, Madrid, Spain). The broth was centrifuged at $10,000 \mathrm{xg}$ for $10 \mathrm{~min}$ to obtain the cell-free culture supernatant (CFCS). The CFCS was filtered through a $0.45 \mu \mathrm{m}$ filter (Prat Dumas, France) to remove residual cells. PCA plates were separately swabbed with standardised fresh culture suspensions (adjusted to $10^{7} \mathrm{cfu} / \mathrm{mL}$ ) of S. enterica, E. coli ATCC 25922, and S. aureus ATCC 25923. A $100 \mu \mathrm{L}$ of CFCS was placed in $4 \mathrm{~mm}$ diameter wells created in the inoculated PCA plates and incubated at $37^{\circ} \mathrm{C}$ for $24 \mathrm{~h}$. The inhibition zone diameter was measured in $\mathrm{mm}$. To examine if the antimicrobial activity was mediated by organic acids, the $\mathrm{pH}$ of the CFCS used was adjusted to 6.5 using $1 \mathrm{M}$ $\mathrm{NaOH}$. To test for heat stability of the active antimicrobial compound, CFCS heated at $100^{\circ} \mathrm{C}$ for $15 \mathrm{~min}$ was used. Proteinase $\mathrm{K}$ sensitivity was determined using CFCS to which $1 \mathrm{mg} / \mathrm{mL}$ of the enzyme (Qiagen Sciences Inc, Germantown, USA) had been added, and the mixture was incubated at $37^{\circ} \mathrm{C}$ for $3 \mathrm{~h}$.

(3) Statistical Analyses. All experiments were performed in duplicate. The data were analyzed using analysis of variance to test for significant differences at an $\alpha$ value of 5\%. Tukey's HSD test was used to separate the means. Analyses were performed by XLSTAT software (version 2010.5.02, Addinsoft, France).

\section{Results and Discussion}

3.1. Acid and Bile Tolerance. The trends in counts of LAB exposed to $\mathrm{pH}=3$ and $1 \%$ bile salts are shown in Table 2 . There was a one log decline in cell counts in both treatments throughout the incubation period. Nevertheless, like the reference strain, the counts of starter cultures were above 6 $\log \mathrm{cfu} / \mathrm{mL}$ at the end of the experiments.

Gastric juice and bile salts are biological barriers in the stomach and duodenum, respectively, that can be inhibitory to many microorganisms [43]. Therefore, probiotics need to survive passage through the stomach, where $\mathrm{pH}$ can be as low as $\leq 3.0$, and stay alive for $2-4 \mathrm{~h}$ [44-46]. Similarly, they must survive passage in the duodenum where bile salt levels can be high as $0.7 \%$ [47]. Surviving in these harsh gastric conditions enables probiotics to reach the ileum alive, colonize it, and impart their benefits [48]. Table 2 shows that the starter cultures survived $\mathrm{pH}=3$ for $3 \mathrm{~h}$ and cell counts were still above the minimum $(6.0 \log \mathrm{cfu} / \mathrm{mL})$ required of probiotic cultures [49]. The survival of microorganisms in gastric juice is attributed to generation of a proton motive force, which expels protons from the cells, thus maintaining a normal intracellular $\mathrm{pH}$ [48]. Tolerance to bile is a prerequisite for colonization and metabolic activity of probiotics in the ileum $[43,50]$. Bile salts are known to have antimicrobial effects against some microorganisms [51] and may slow down growth [52]. They can disrupt the microbial cellular homeostasis as well as dissociate the lipid bilayer and integrity of the cell membrane resulting in cell death [12]. However, some LAB produce bile salts hydrolase (BSH) which hydrolyzes conjugated bile salts, thus lowering their toxicity [45]. The average bile concentration in the 
TABle 2: Microbial counts of lactic acid bacteria starters exposed to high acid $(\mathrm{pH}=3)$ and $1 \%$ bile.

\begin{tabular}{|c|c|c|c|c|c|c|c|c|}
\hline \multirow{3}{*}{ Time (h) } & \multicolumn{8}{|c|}{ Microbial counts $(\log \mathrm{cfu} / \mathrm{mL})$} \\
\hline & \multicolumn{2}{|c|}{$\begin{array}{c}\text { Lactobacillus rhamnosus } \\
\text { yoba } 2012\end{array}$} & \multicolumn{2}{|c|}{$\begin{array}{l}\text { Weissella confusa MNC } \\
20\end{array}$} & \multicolumn{2}{|c|}{$\begin{array}{c}\text { Lactobacillus plantarum } \\
\text { MNC } 21\end{array}$} & \multicolumn{2}{|c|}{$\begin{array}{c}\text { Lactococcus lactis MNC } \\
24\end{array}$} \\
\hline & $\mathrm{pH}=3$ & 1\% bile & $\mathrm{pH}=3$ & 1\% bile & $\mathrm{pH}=3$ & $1 \%$ bile & $\mathrm{pH}=3$ & $1 \%$ bile \\
\hline 0 & $8.7^{\mathrm{a}} \pm 0.0$ & $8.2^{\mathrm{a}} \pm 0.1$ & $9.0^{\mathrm{a}} \pm 0.0$ & $8.1^{\mathrm{a}} \pm 0.0$ & $8.9^{\mathrm{a}} \pm 0.0$ & $8.8^{\mathrm{a}} \pm 0.1$ & $8.5^{\mathrm{a}} \pm 0.1$ & $8.6^{\mathrm{a}} \pm 0.0$ \\
\hline 3 & $7.7^{\mathrm{b}} \pm 0.1$ & $8.1^{\mathrm{ab}} \pm 0.0$ & $8.4^{\mathrm{b}} \pm 0.0$ & $8.0^{\mathrm{a}} \pm 0.0$ & $8.1^{\mathrm{b}} \pm 0.1$ & $8.3^{\mathrm{b}} \pm 0.1$ & $7.2^{\mathrm{b}} \pm 0.1$ & $8.4^{\mathrm{b}} \pm 0.0$ \\
\hline 6 & & $7.6^{\mathrm{b}} \pm 0.0$ & & $7.6^{\mathrm{b}} \pm 0.0$ & & $7.8^{\mathrm{c}} \pm 0.0$ & & $8.0^{\mathrm{c}} \pm 0.0$ \\
\hline 9 & & $7.2^{\mathrm{C}} \pm 0.0$ & & $7.5^{\mathrm{b}} \pm 0.0$ & & $7.3^{\mathrm{d}} \pm 0.0$ & & $7.8^{\mathrm{d}} \pm 0.0$ \\
\hline
\end{tabular}

Values are means \pm standard deviations of three independent determinations. Mean values in the same column with the same superscripts are not significantly different $(p>0.05)$

duodenum is about $0.3 \%$ [53, 54]. Goldin and Gorbach [55] recommend $0.15-0.3 \%$ bile for probiotics screening. In this study, all isolates tolerated broth containing $1 \%$ bile salts (Table 2). In fact, at the end of the $9 \mathrm{~h}$ of exposure to bile, the counts were above the minimum $(6.0 \log \mathrm{cfu} / \mathrm{mL})$ required for probiotic effect [49]. These findings are in agreement with those of several authors $[54,56,57]$.

3.1.1. Bile Salt Hydrolase (BSH). The BSH activity of the LAB is summarized in Table 3 . The intensity of hydrolysis was in the order as follows: $W$. confusa MNC $20>\mathrm{Lb}$. plantarum MNC $21>$ L. lactis MNC $24>$ Lb. rhamnosus yoba 2012.

BSH is an enzyme produced by intestinal microflora that catalyzes the deconjugation of glycine- or taurine-linked bile salts [58]. The ability of the LAB starters to produce BSH was concomitant with their ability to tolerate bile salts (Table 2). These findings are in agreement with those of other authors who also reported BSH activity in LAB $[14,16,20,59]$. Deconjugation of bile salts reduces their toxicity, thus enabling probiotic $\mathrm{LAB}$ to survive in the duodenum $[45,60]$. Deconjugated bile salts are lethal to some pathogens [61], and therefore, BSH activity by the LAB starters could contribute towards their antimicrobial properties. The mechanism by which probiotics protect themselves against these deconjugated salts is yet to be understood. Deconjugated bile salts not only inhibit pathogens but also are associated with reduction of serum cholesterol $[4,61]$. This is because deconjugated bile salts are poorly reabsorbed in the liver, which results in their excretion in stool. This increases the demand for serum cholesterol for the de novo synthesis of bile salts in the liver $[4,62]$. The LAB starters in this study may therefore possess cholesterol-lowering effects. This property is particularly useful for individuals with hypercholesterolemia.

\subsection{Safety of the LAB Starters}

3.2.1. Antibiotic Susceptibility. Table 1 shows the susceptibility of the LAB to different antibiotics. Antibiotic susceptibility categorized as "susceptible," "moderately susceptible," and "resistant" was based on the study by Charteris et al. [33]. However, susceptibility to amoxicillin, cephalexin, streptomycin, levofloxacin, and novobiocin against LAB is currently not documented. Therefore, susceptibility to these was based on antibiotics within their
TABLE 3: Bile salt hydrolase activity of lactic acid bacteria isolates.

\begin{tabular}{lcc}
\hline Lactic acid bacteria & Hydrolysis zone $(\mathrm{mm})$ & BSH activity \\
\hline Lb. rhamnosus yoba 2012 & $6.3^{\mathrm{d}} \pm 1.1$ & Low \\
L. lactis MNC 24 & $7.3^{\mathrm{c}} \pm 1.4$ & Low \\
Lb. plantarum MNC 21 & $10.7^{\mathrm{b}} \pm 1.4$ & Medium \\
W. confusa MNC 20 & $12.6^{\mathrm{a}} \pm 1.7$ & Medium \\
\hline
\end{tabular}

Values are means \pm standard deviations of three independent determinations. Values in the same column with the same superscripts are not significantly different $(p>0.05)$. BSH activity was categorized based on diameter of zones of hydrolysis as low BSH activity (up to $10 \mathrm{~mm}$ ), medium BSH activity (11-15 $\mathrm{mm})$, and high BSH activity $(>16 \mathrm{~mm})$ [16].

classes. Results showed that the Obushera LAB starter cultures and reference probiotic were resistant to 10 and 5 of 21 antibiotics, respectively. The Obushera starters were generally resistant to penicillin G, ampicillin, vancomycin, gentamycin, kanamycin, tetracycline, ciprofloxacin, metronidazole, sulphamethoxazole-trimethoprin, and colistin. $L b$. rhamnosus yoba 2012 was only resistant to vancomycin, kanamycin, metronidazole, sulphamethoxazole-trimethoprim, and colistin.

Antibiotic resistance is inherent in some LAB, and the mechanisms involved include absence of a target, low permeability, antibiotic inactivation, and presence of efflux mechanisms, among others [12]. There are concerns that some antibiotic resistant $\mathrm{LAB}$ may be reservoirs of antibiotic resistance genes that could be transferred to pathogens $[63,64]$. However, with intrinsic resistance, the risk of resistance gene transfer is not only still speculative but also practically impossible $[12,65]$. For instance, Lactobacilli are known to have a high natural chromosomally encoded resistance to vancomycin [66]. This resistance is due to the absence of $D$-Ala- $D$-lactate in their cell wall which is the target for vancomycin; therefore, such resistance is nontransferable $[67,68]$. The natural resistance of Lactobacilli to vancomycin could thus explain the results in Table 1. In fact, these results are in agreement with those of Zhou et al. [69] and Leite et al. [70]. In addition, the resistance of Lactobacilli to aminoglycosides such as gentamycin, kanamycin, and streptomycin is also thought to be intrinsic by Hummel et al. [71]. The resistance of $L A B$ to penicillin $G$, ampicillin, vancomycin, gentamycin, kanamycin, tetracycline, ciprofloxacin, metronidazole, sulphamethoxazole-trimethoprin, and colistin is also reported elsewhere [66] [16, 57, 68, 72]. The susceptibility of the LAB species evaluated in this study to some antibiotics such as erythromycin, rifampicin, and 
chloramphenicol has also been reported in other studies $[16,33,57,70]$.

Antibiotic resistance among probiotic microorganisms could be a desirable trait because it guarantees their survival and thus maintains the natural balance of intestinal microflora even when a host is on antibiotic therapy [73]. This study showed that the starter cultures were resistant to some of the commonly prescribed antibiotics (penicillin G, ampicillin, gentamicin, tetracycline, ciprofloxacin, metronidazole, sulphamethoxazoletrimethoprim, and nitrofurantoin) in Uganda. This implies that administration of these antibiotics in combination with the LAB cultures will not affect their survival in the GIT. However, amoxicillin-clavulanic acid, ceftriaxone, erythromycin, chloramphenicol, rifampicin, or nitrofurantoin treatment will necessitate readministration of the LAB after the antibiotic therapy to allow for recolonization of the intestinal lumen.

3.2.2. Production of Biogenic Amines. The LAB did not decarboxylate L-histidine, L-tyrosine, L-phenylalanine, L-lysine, and L-ornithine. Only Lb. plantarum MNC 21 and $W$. confusa MNC 20 decarboxylated L-arginine, but the extent, indicated by a light purple coloration of the decarboxylation medium, was low.

In order to survive in an acidic environment as is the case in many fermented foods, some LAB decarboxylate amino acids leading to an increase in $\mathrm{pH}$ [74]. Additionally, decarboxylation of amino acids results in the formation of biogenic amines: histamine from L-histidine, tyramine from L-tyrosine, cadaverine from L-lysine and L-tyrosine, phenylethylamine from L-phenylalanine and L-ornithine, agmatine from L-arginine, and putrescine from L-phenylalanine and L-ornithine [75]. According to Galgano et al. [76], biogenic amines are produced in all living organisms and play a vital role in cell growth and development. In fact, these amines are also present in the diet but concern is with the amount consumed. Ingestion of biogenic amines in large amounts can trigger toxic reactions such as vasoactivity and psychoactivity affecting the vascular and nervous systems, respectively, [75]. In addition, in the presence of nitrites, biogenic amines can be converted to nitrosoamines in foods [77]. Histamine, tyramine, and phenylethylamine are the biggest concerns, given their serious toxicological effects [75]. On the other hand, putrescine and cadaverine are not toxic but rather enhance the toxic effects of histamine and tyramine [78]. Unfortunately, the threshold of biogenic amine intoxication is difficult to establish since it is dependent on individual responses [79].

Fortunately, the LAB in this study did not produce histamine, tyramine, phenylethylamine, putrescine, or cadaverine. Although production of these biogenic amines was not observed in this study, some researchers have reported otherwise for certain Lactobacilli and Lactococci strains [79-81]. This illustrates the strain specific nature of this property among microorganisms.

In contrast, $L b$. plantarum MNC 21 and $W$. confusa MNC 20 produced agmatine. This is not worrisome because according to Galgano et al. [76], agmatine acts as a neurotransmitter or neuromodulator, stimulates insulin release, and suppresses tumors in the body. In fact, since a limited amount of agmatine is produced in mammalian cells, Galgano et al. [76] suggest that food should contain sufficient amounts to meet the body requirements. Therefore, the ability of $L b$. plantarum MNC 21 and W. confusa MNC 20 to produce agmatine is a useful trait that could be exploited to enhance agmatine levels in fermented foods.

3.2.3. Mucin Degradation. The contribution of mucin and glucose to the growth of LAB is summarized in Figure 1. Results showed that the LAB lacked mucolytic ability. This was shown by the net cell growth in the basal media (BM) and the BM with mucin not being different $(p>0.05)$. Results showed the ability of the unheated fecal microorganims (FM) to grow in the BM containing mucin, an indication of their ability to degrade and utilize mucin as the sole carbon source.

The GIT is covered by a mucus layer which provides a protective barrier for the underlying epithelium against pathogens and chemical, physical and enzymatic damage [82]. Therefore, microbial mucin degradation is considered a pathogenicity factor since it exposes the intestinal lumen to pathogens [83]. Mucin is an energy source for some intestinal microorganisms, and about $1 \%$ of the colonic microbiota can degrade host mucin [84]. The presence of mucin degrading bacteria in the intestine explains the differences in results of the positive and negative controls in this study (Figure 1). Mucolytic ability by mixed intestinal populations has been widely studied $[82,85]$. Some specific intestinal microbes with this ability include Bacteroides fragilis and Clostridium perfringens as well as certain strains of Bifidobacterium longum, Bifidobacterium bifidum, and Bifidobacterium breve [86-88]. Therefore, given that LAB also form part of the intestinal microbiota, it is important that those intended for probiotic use are screened for mucolytic ability and more so, since the capabilities of all probiotics are not the same $[35,89]$. Fortunately, the LAB were unable to degrade mucin (Figure 2). These findings are in agreement with those of other authors $[83,90]$.

\subsection{Potential Probiotic Benefits of the LAB Starters}

\subsubsection{Indicators of Ileal Adherence}

(1) Hydrophobicity and Auto-Aggregation. The hydrophobicity and auto-aggregation of the LAB are shown in Table 4 . Lb. rhamnosus yoba 2012 showed the highest $(p<0.05)$ auto-aggregation and hydrophobicity. For the starter cultures, hydrophobicity was in the order of $L b$. plantarum MNC $21>W$. confusa MNC $20>$ L. lactis MNC 24. The hydrophobicity of the starter cultures in either solvent was similar $(p<0.05)$. The highest $(p<0.05)$ auto-aggregation after $5 \mathrm{~h}$ of incubation was in Lb. plantarum MNC 21. After $24 \mathrm{~h}$ of incubation, all isolates had $100 \%$ auto-aggregation.

Hydrophobicity is a measure of the relative tendency of a substance to prefer a nonaqueous environment rather than 


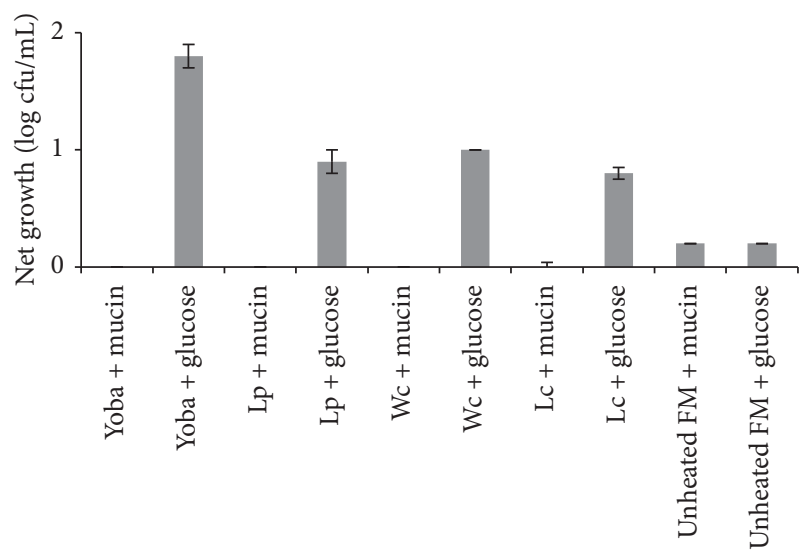

Treatments

FIGURE 1: Effect of mucin and glucose on cell growth. Error bars show standard deviations of three independent determinations. Yoba: Lactobacillus rhamnosus yoba 2012; Lp: Lactobacillus plantarum MNC 21; Wc: Weissella confusa MNC 20; Lc. Lactococcus lactis MNC 24; FM; fecal microbes.

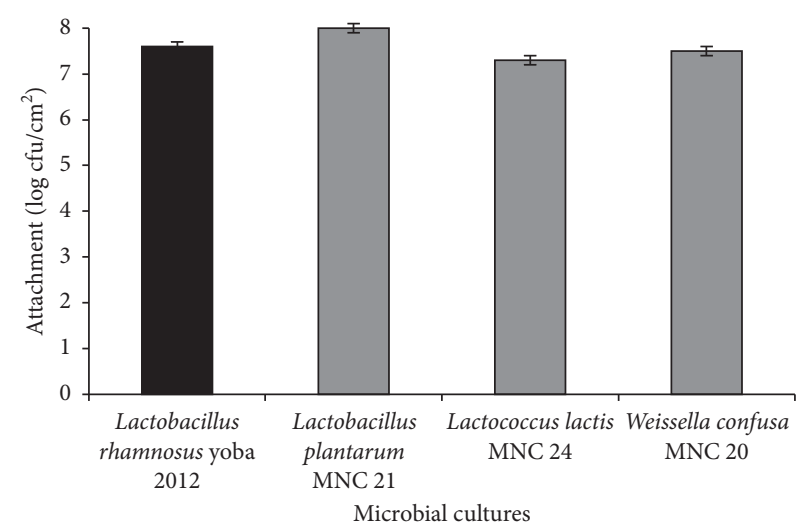

FIgURE 2: Attachment of lactic acid bacteria to goat ileum. Error bars show standard deviations of three independent determinations.

an aqueous environment [91]. Auto-aggregation refers to the aggregation of genetically identical bacteria cells [92]. Both hydrophobicity and auto-aggregation relate to the ability of the microbial cells to adhere to epithelial cells and mucosal surfaces $[93,94]$. This is important for formation of biofilms, competition, and colonization in the GIT $[95,96]$. It is the hydrophobic nature of the microbial cell surface that enables it attach to the intestinal surface [97]. In this study, the isolates exhibited varying hydrophobicity and auto-aggregation properties, indicating ability to adhere onto the intestinal epithelium and resist the peristaltic movement of food. Lb. rhamnosus yoba 2012 was more $(p<0.05)$ hydrophobic than the starter cultures. Nonetheless, the hydrophobicity of the starters in xylene and toluene were similar to values (6-79\%) reported for other LAB $[39,62,98,99]$. Generally, the hydrophobicity was higher $(p<0.05)$ in toluene than in xylene. Indeed, variations in \% hydrophobicity of microorganisms in different solvents have been reported $[98,100]$. The lack of hydrophobicity among $\mathrm{LAB}$ is also documented. Tomáška et al. [38] reported $<1 \%$ hydrophobicity in some Lactobacilli, implying their lack of adhesion properties. The differences in hydrophobicity among $\mathrm{LAB}$ are attributed to the extent of expression of the cell surface proteins [101-103].

The hydrophobicity (4.3-18.3\%) of the starter cultures were lower than the minimum (40\%) that some authors considered while screening for probiotic microorganisms [104]. Indeed, Del Re et al. [105] and Pérez et al. [106] stated that $40 \%$ was the minimum for adhesion capabilities. However, the justification for this criterion is not stated. Even so, $4.3-18.3 \%$ could be significant in aiding adhesion, and more so, if high doses of the culture are ingested.

Table 4 shows that the starter cultures are strongly selfaggregative moreover, to the same extent as the reference strain. In fact, the results were generally higher than those observed $(0-70 \%)$ by others $[39,96,98,107]$. Studies have reported a direct relationship between hydrophobicity and auto-aggregation $[98,104,108]$. However, in this study, hydrophobicity was generally much lower than auto-aggregation. The disparity between hydrophobicity and autoaggregation confirmed previous findings that hydrophobicity results alone do not necessarily correlate with adhesion properties [97, 107]. Hydrophobicity and autoaggregation are merely preliminary screening tests for adherent bacteria [105]. Therefore, ex vivo or in vivo adhesion assays have to be performed to substantiate the adhesion ability.

(2) Attachment to Goat Ileum. Figure 2 summarizes the level of attachment of the LAB to the goat ileum. Results indicated the ability of candidate LAB to attach onto the ileum almost to the same extent as the reference strain. $L b$. plantarum MNC 21 and L. lactis MNC 24 showed higher $(p<0.05)$ and similar $(p>0.05)$ attachment than the reference strain, respectively.

Probiotics need to first attach themselves onto the epithelium of the ileum before they can confer health benefits to their host [109]. The attachment to a certain extent enables them to resist the peristaltic movement of the GIT [38]. Additionally, their adhesion displaces pathogens from the luminal-mucosa interface through competition for binding sites on the epithelial and/or mucosal surfaces [94, 110]. Studies have also reported that the adhesion of some probiotic microorganisms onto the ileal epithelium triggers certain immunological responses. Probiotic attachment can also enhance gut barrier function and reduce its permeability to pathogens and antigens $[111,112]$. In addition, their attachment to the ileum can stimulate the secretion of antimicrobial compounds by the intestinal epithelial cells $[110,113,114]$.

According to Cunha et al. [18], the beneficial effect of a probiotic to its host is related to its concentration in the ileal lumen. The concentration required to obtain a clinical effect is at least $6-7 \log \mathrm{cfu} / \mathrm{mL}$ or $\mathrm{g}$ in the ileum $[18,115]$. The ability of the starter cultures to attach onto the epithelium of the ileum at 7.3-8.0 $\mathrm{log} \mathrm{cfu} / \mathrm{cm}^{2}$ (Figure 2) is an excellent property. Even though, according to Pérez et al. [106] and Iñiguez-Palomares et al. [104], the hydrophobicity results of our LAB starters (Table 4) are too low to consider them for 
TABLE 4: Auto-aggregation and hydrophobicity of lactic acid bacteria.

\begin{tabular}{lccrc}
\hline \multirow{2}{*}{ Lactic acid bacteria } & \multicolumn{2}{c}{ \% hydrophobicity } & \multicolumn{2}{c}{ \% auto-aggregation } \\
& Xylene & Toluene & $5 \mathrm{~h}$ & $24 \mathrm{~h}$ \\
\hline Lactobacillus rhamnosus yoba 2012 & $80.3^{\mathrm{a}} \pm 3.2$ & $66.3^{\mathrm{a}} \pm 2.8$ & $100.0^{\mathrm{a}} \pm 0.0$ & $100.0^{\mathrm{a}} \pm 0.0$ \\
Lactobacillus plantarum MNC 21 & $15.9^{\mathrm{b}} \pm 1.5$ & $12.6^{\mathrm{b}} \pm 1.7$ & $100.0^{\mathrm{a}} \pm 0.0$ & $100.0^{\mathrm{a}} \pm 0.0$ \\
Lactococcus lactis MNC 24 & $5.5^{\mathrm{c}} \pm 2.7$ & $5.9^{\mathrm{d}} \pm 2.4$ & $75.8^{\mathrm{c}} \pm 2.9$ & $100.0^{\mathrm{a}} \pm 0.0$ \\
Weissella confusa MNC 20 & $4.3^{\mathrm{d}} \pm 0.5$ & $8.4^{\mathrm{c}} \pm 2.7$ & $79.9^{\mathrm{d}} \pm 2.0$ & $100.0^{\mathrm{a}} \pm 0.0$ \\
\hline
\end{tabular}

Values are means \pm standard deviations of three independent determinations. Mean values in the same column with similar superscripts are not significantly different $(p>0.05)$

TABLE 5: Percentage coaggregation of lactic acid bacteria with selected pathogens.

\begin{tabular}{|c|c|c|c|}
\hline \multirow{2}{*}{ Lactic acid bacteria } & \multicolumn{3}{|c|}{ Pathogenic bacteria } \\
\hline & Escherichia coli ATCC 25922 & Staphylococcus aureus ATCC 25923 & Salmonella enterica \\
\hline Lb. rhamnosus yoba 2012 & $17.2^{\mathrm{a}} \pm 0.2$ & $87.0^{\mathrm{a}} \pm 0.2$ & $73.3^{\mathrm{a}} \pm 0.2$ \\
\hline Lb. plantarum MNC 21 & $12.6^{\mathrm{c}} \pm 0.1$ & $33.8^{\mathrm{c}} \pm 0.2$ & $61.7^{\mathrm{b}} \pm 0.1$ \\
\hline W. confusa MNC 20 & $11.3^{\mathrm{d}} \pm 0.0$ & $69.1^{\mathrm{b}} \pm 0.0$ & $56.4^{\mathrm{c}} \pm 0.3$ \\
\hline L. lactis MNC 24 & $16.2^{\mathrm{b}} \pm 0.2$ & $13.8^{\mathrm{d}} \pm 0.1$ & $23.8^{\mathrm{d}} \pm 0.1$ \\
\hline
\end{tabular}

Values are means \pm standard deviations of three independent determinations. Mean values in the same column with same superscripts are not significantly different $(p>0.05)$.

adhesion capabilities, results from the ex vivo assay (Figure 2) indicate otherwise. This further illustrates that hydrophobicity may not be a good proxy indicator for adhesion to the epithelium.

\subsubsection{Pathogen Inhibition}

(1) Coaggregation. There were variations in the coaggregation abilities of the LAB with S. aureus ATCC 25923, E. coli ATCC 25922, and S. enterica (Table 5). Lb. rhamnosus yoba 2012 showed the highest $(p<0.05)$ coaggregation with the three isolates. Among the isolates, the highest coaggregations were $W$. confusa MNC 20 with S. aureus ATCC 25923 (69.1\%), Lb. plantarum MNC 21 with S. enterica (61.7\%), and L. lactis MNC 24 with E. coli ATCC 25922 (16.2\%). Generally, the isolates coaggregated most with $S$. enterica and least with E. coli ATCC 25922.

Coaggregation is the aggregation of genetically distinct bacterial cells [92]. It is important in preventing the attachment of pathogens onto the intestinal mucosa [116]. Furthermore, through coaggregation, LAB secrete antimicrobial compounds in close proximity with pathogens inhibiting their survival in the GIT $[104,117,118]$. From the results, it appears that $L$. lactis MNC 24, W. confusa MNC 20, and L. plantarum MNC 21 would be most effective in inhibiting E. coli, Staphylococcus, and Salmonella, respectively. The observed coaggregation of the cultures with $E$. coli, Staphylococcus, and Salmonella is in agreement with that of other researchers. For instance, coaggregations of our LAB with $S$. enterica and S. aureus ATCC 25923 (13.8-87.0\%) were similar to those (21-49\%) of Arief et al. [119]. However, \% coaggregations with E. coli 25922 (11.3-17.2\%) were slightly lower than the values (21-39\%) reported by the same authors but were in agreement $(15.1 \%)$ with those by Kos et al. [39]. The \% coaggregation with $S$. enterica $(23.8-73.3 \%)$ was higher than the value $(15.7 \%)$ reported by Kos et al. [39]. These discrepancies imply variations in cell surfaces and cell-binding properties of LAB [120].

(2) Production of Antimicrobial Compounds. The antimicrobial effect of the LAB is summarized in Table 6. The isolates had an inhibitory effect against E. coli ATCC 25922, Staphylococcus aureus ATCC 25923, and Salmonella enterica. Neutralization of the CFCS eliminated its inhibitory effect. Additionally, the action of bacteriocins in the CFCS was not detected.

The antimicrobial action of LAB is attributed to their metabolites, including organic acids, bacteriocins, hydrogen peroxide, ethanol, and diacetyl, among others [25]. The starter culture isolates in this study are fast and high producers of lactic acid [21, 26]. Therefore, lactic acid was possibly the principle microbial inhibitor in this study. In fact, when the $\mathrm{pH}$ of CFCS was adjusted to 6.5, its antimicrobial effect disappeared (Table 6). Furthermore, the inability of the heat-and protease-treated CFCS to inhibit microbial growth ruled out the action of bacteriocins. Indeed, similar studies reported that a $\mathrm{pH}$-dependent mechanism was responsible for the antimicrobial activity of LAB $[121,122]$. Lactic acid inhibits microorganisms by lowering the extracellular $\mathrm{pH}$ and permeabilizing the outer cellular membrane [123]. This collapses the electrochemical proton gradient of the cells which in turn disrupts cellular function and enables the adverse effects of other antimicrobial compounds [123, 124]. The antimicrobial activity of the starter cultures suggests their potential application in promoting the safety of fermented food products.

Although in vitro tests are not conclusive means for screening microbes for probiotic properties, they provide an important initial lead. Our findings indicate potential probiotic activity of the Obushera starter cultures, but further in vivo confirmatory studies are required. The probiotic potential of the Obushera LAB only extends to the comparison 
TABLe 6: Antimicrobial activity of lactic acid bacteria isolates.

\begin{tabular}{|c|c|c|c|}
\hline Cell-free culture supernatant treatment & Escherichia coli ATCC 25922 & Staphylococcus aureus ATCC 25923 & Salmonella enterica \\
\hline \multicolumn{4}{|l|}{ No treatment } \\
\hline Lactobacillus rhamnosus yoba 2012 & + & + & + \\
\hline Weissella confusa MNC 20 & + & + & + \\
\hline Lactobacillus plantarum MNC 21 & + & + & + \\
\hline Lactococcus lactis MNC 24 & + & + & + \\
\hline \multicolumn{4}{|l|}{$\mathrm{pH}=6.5$} \\
\hline Lactobacillus rhamnosus yoba 2012 & - & - & - \\
\hline Weissella confusa MNC 20 & - & - & - \\
\hline Lactobacillus plantarum MNC 21 & - & - & - \\
\hline Lactococcus lactis MNC 24 & - & - & - \\
\hline \multicolumn{4}{|l|}{$100^{\circ} \mathrm{C}$ for $15 \mathrm{~min}$} \\
\hline Lactobacillus rhamnosus yoba 2012 & + & + & + \\
\hline Weissella confusa MNC 20 & + & + & + \\
\hline Lactobacillus plantarum MNC 21 & + & + & + \\
\hline Lactococcus lactis MNC 24 & + & + & + \\
\hline \multicolumn{4}{|l|}{ Proteinase $\mathrm{K}\left(37^{\circ} \mathrm{C}, 3 \mathrm{~h}\right)$} \\
\hline Lactobacillus rhamnosus yoba 2012 & + & + & + \\
\hline Weissella confusa MNC 20 & + & + & + \\
\hline Lactobacillus plantarum MNC 21 & + & + & + \\
\hline Lactococcus lactis MNC 24 & + & + & + \\
\hline
\end{tabular}

Inhibition zone diameter: $-(<11 \mathrm{~mm}) ;+(11-16 \mathrm{~mm})[16]$.

with a single reference probiotic Lb. rhamnosus yoba 2012. Nonetheless, ability of the cultures to tolerate simulated gastrointestinal conditions, pose no safety risk, deconjugate bile salts, adhere to the ileum, and inhibit different pathogenic species is significant in the improvement of health and the safety of fermented food products.

\section{Data Availability}

The data in tables and figures used to support the findings of this study are included within the article.

\section{Conflicts of Interest}

The authors declare that they have no conflicts of interest.

\section{Acknowledgments}

The authors acknowledge Dr. Joseph Haumba for providing the amino acids used in this study. This research was funded by Mr. Samuel K. Byakika.

\section{References}

[1] FAO/WHO, Evaluation of health and nutritional properties of probiotics in food including powder milk with live lactic acid bacteria, FAO/WHO, Rome, Italy, 2006.

[2] G. Reid, "Instillation of Lactobacillus and stimulation of indigenous organisms to prevent recurrence of urinary tract infections," Microecological Theory, vol. 23, pp. 32-45, 1995.

[3] J. G. Leblanc, C. Burgess, F. Sesma, G. S. De Giori, and D. Van Sinderen, "Lactococcus lactisis capable of improving the riboflavin status in deficient rats," British Journal of Nutrition, vol. 94, no. 2, pp. 262-267, 2005.

[4] M. Begley, C. Hill, and C. G. M. Gahan, "Bile salt hydrolase activity in probiotics," Applied and Environmental Microbiology, vol. 72, no. 3, pp. 1729-1738, 2006.
[5] M. Kumar, A. Kumar, R. Nagpal et al., "Cancer-preventing attributes of probiotics: an update," International Journal of Food Sciences and Nutrition, vol. 61, no. 5, pp. 473-496, 2010.

[6] M. Kechagia, D. Basoulis, S. Konstantopoulou et al., "Health benefits of probiotics: a review," ISRN Nutrition, vol. 2013, Article ID 481651, 7 pages, 2013.

[7] T. Nangia, V. Setia, G. Kochhar, K. Kaur, R. Bansal, and R. Sharma, "Probiotics: review of literature," Journal of Periodontal Medicine \& Clinical Practice, vol. 1, pp. 144-151, 2014.

[8] E. V. Prazdnova, V. A. Chistyakov, M. N. Churilov et al., "DNA-protection and antioxidant properties of fermentates fromBacillus amyloliquefaciensB-1895 andBacillus subtilisKATMIRA1933," Letters in Applied Microbiology, vol. 61, no. 6, pp. 549-554, 2015.

[9] I. Biviano, S. Rossi, D. Piacentino et al., "Effect of Bifidobacterium longum Bb536 Plus Lactoferrin in the treatment of irritable bowel syndrome. A double blind clinical trial," Advanced Research in Gastroenterology \& Hepatology, vol. 6, pp. 1-4, 2017.

[10] P. Zolotukhin, E. Prazdnova, and V. Chistyakov, "Methods to assess the antioxidative properties of probiotics," Probiotics Antimicrob Proteins, vol. 1, p. 11, 2017.

[11] M. Saxelin, S. Tynkkynen, T. Mattila-Sandholm, and W. M. De Vos, "Probiotic and other functional microbes: from markets to mechanisms," Current Opinion in Biotechnology, vol. 16, no. 2, pp. 204-211, 2005.

[12] Z. Radulović, T. Petrović, and S. Bulajić, "Antibiotic susceptibility of probiotic bacteria," 2012, http://cdn.intechopen.com/pdfs/ 34710/InTech-Antibiotic_susceptibility_of_probiotic_bacteria.pdf.

[13] A. M. Mahasneh and M. M. Abbas, "Probiotics and traditional fermented foods: the eternal connection: mini review," Jordan Journal of Biological Sciences, vol. 147, pp. 1-14, 2010.

[14] I. S. Surono, "In vitro probiotic properties of indigenous dadih lactic acid bacteria," Asian-Australasian Journal of Animal Sciences, vol. 16, no. 5, pp. 726-731, 2003.

[15] Y. Duangjitcharoen, D. Kantachote, M. Ongsakul, N. Poosaran, and C. Chaiyasut, "Selection of probiotic lactic 
acid bacteria isolated from fermented plant beverages," Pakistan Journal of Biological Sciences: PJBS, vol. 11, no. 4, pp. 652-655, 2008.

[16] J. Mathara, U. Schillinger, C. Guigas et al., "Functional characteristics of Lactobacillus spp. from traditional Maasai fermented milk products in Kenya," International Journal of Food Microbiology, vol. 126, no. 1-2, pp. 57-64, 2008.

[17] A. Belicová, M. Mikulášová, and R. Dušinský, "Probiotic potential and safety properties of Lactobacillus plantarum from Slovak Bryndza cheese," BioMed Research International, vol. 2013, Article ID 760298, 8 pages, 2013.

[18] A. F. Cunha, L. B. Acurcio, B. S. Assis et al., "In vitro probiotic potential of Lactobacillus spp. isolated from fermented milks," Arquivo Brasileiro de Medicina Veterinária e Zootecnia, vol. 65, no. 6, pp. 1876-1882, 2013.

[19] D. Borah, O. Gogoi, C. Adhikari, and B. B. Kakoti, "Isolation and characterization of the new indigenous Staphylococcus sp. DBOCP06 as a probiotic bacterium from traditionally fermented fish and meat products of Assam state," Egyptian Journal of Basic and Applied Sciences, vol. 3, no. 3, pp. 232-240, 2016.

[20] H. Burhan, S. A. Priyambada, E. Taufik, and Arief II, "Potential of lactic acid bacteria isolated from dangke and Indonesian beef as hypocholesterolaemic agent," Media Peternakan, vol. 40, no. 2, pp. 136-142, 2017.

[21] I. M. Mukisa, "Sensory characteristics, microbial diversity and starter culture development for obushera, a traditional cereal fermented beverage from Uganda," University of Life Sciences, Uganda, Dissertation, 2012.

[22] C. M. B. K. Muyanja, J. A. Narvhus, J. Treimo, and T. Langsrud, "Isolation, characterisation and identification of lactic acid bacteria from bushera: a Ugandan traditional fermented beverage," International Journal of Food Microbiology, vol. 80, no. 3, pp. 201-210, 2003.

[23] I. M. Mukisa, D. Porcellato, Y. B. Byaruhanga et al., "The dominant microbial community associated with fermentation of Obushera (sorghum and millet beverages) determined by culture-dependent and culture-independent methods," International Journal of Food Microbiology, vol. 160, no. 1, pp. 1-10, 2012.

[24] V. Plengvidhya, F. Breidt, Z. Lu, and H. P. Fleming, "DNA fingerprinting of lactic acid bacteria in sauerkraut fermentations $\dagger$," Applied and Environmental Microbiology, vol. 73, no. 23, pp. 7697-7702, 2007.

[25] P. Rattanachaikunsopon and P. Phumkhachorn, "Lactic acid bacteria: their antimicrobial compounds and their uses in food production," Annals of Biological Research, vol. 1, pp. 218-228, 2010.

[26] I. M. Mukisa, D. Ntaate, and S. Byakika, "Application of starter cultures in the production of Enturire - a traditional sorghum-based alcoholic beverage," Food Science \& Nutrition, vol. 5, no. 3, pp. 609-616, 2017.

[27] Joint FAO/WHO Working Group, Report on Drafting Guidelines for the Evaluation of Probiotics in Food, FAO and WHO, London, UK, 2002.

[28] N. K. Ganguly, S. K. Bhattacharya, B. Sesikeran et al., "ICMRDBT guidelines for evaluation of probiotics in food," Indian Journal of Medical Research, vol. 134, no. 1, pp. 22-25, 2011.

[29] S. Byakika, I. M. Mukisa, Y. B. Byaruhanga, and C. Muyanja, "A review of criteria and methods for evaluating the probiotic potential of microorganisms," Food Reviews International, vol. 35, no. 5, pp. 427-466, 2019.

[30] S. Basu, M. Chatterjee, S. Ganguly, and P. K. Chandra, "Effect of lactobacillus rhamnosus GG in persistent diarrhea in
Indian children," Journal of Clinical Gastroenterology, vol. 41, no. 8, pp. 756-760, 2007.

[31] N. Westerik, G. Reid, W. Sybesma, and R. Kort, "The probiotic Lactobacillus rhamnosus for alleviation of Helicobacter pylori-associated gastric pathology in East Africa," Frontiers in Microbiology, vol. 9, p. 1873, 2018.

[32] Clinical and Laboratory Standard Institute (CLSI), "Performance standards for antimicrobial susceptibility testing," 2013, http://www.facm.ucl.ac.be/intranet/CLSI/CLSIM100S23-susceptibility-testing-2013-no-protection.pdf.

[33] W. P. Charteris, P. M. Kelly, L. Morelli, and J. K. Collins, "Antibiotic susceptibility of potentially probiotic Lactobacillus species," Journal of Food Protection, vol. 61, no. 12, pp. 1636-1643, 1998.

[34] E. Y. Bridson, The Oxoid Manual, Unipath Limited, Basingstoke, UK, 7th edition, 1995.

[35] F. Abe, M. Muto, T. Yaeshima et al., "Safety evaluation of probiotic bifidobacteria by analysis of mucin degradation activity and translocation ability," Anaerobe, vol. 16, no. 2, pp. 131-136, 2010.

[36] L. P. Aristoteli and M. D. Willcox, "Mucin degradation mechanisms by distinct Pseudomonas aeruginosa isolates in vitro," Infection and Immunity, vol. 71, no. 10, pp. 5565-5575, 2003.

[37] D. Beighton, K. Smith, D. A. Glenister, K. Salamon, and C. W. Keevil, "Increased degradative enzyme production by dental plaque bacteria in mucin-limited continuous culture," Microbial Ecology in Health and Disease, vol. 1, no. 2, pp. 85-94, 1988.

[38] M. Tomáška, M. Drončovský, L. Klapáčová, A. Slottová, and M. Kološta, "Potential probiotic properties of Lactobacilli isolated from goat's milk," Potravinarstvo, vol. 9, pp. 66-71, 2015.

[39] B. Kos, J. Š s avai, S. Vuković, M. Š koviai, J. Frece, and S. Matošić, "Adhesion and aggregation ability of probiotic strainLactobacillus acidophilusM92," Journal of Applied Microbiology, vol. 94, no. 6, pp. 981-987, 2003.

[40] S. Abbasiliasi, J. S. Tan, F. Bashokouh et al., "In vitro assessment of Pediococcus acidilactici Kp 10 for its potential use in the food industry," BMC Microbiol, vol. 17, no. 1, p. 121, 2017.

[41] C. G. Vinderola, P. Mocchiutti, and J. A. Reinheimer, "Interactions among lactic acid starter and probiotic bacteria used for fermented dairy products," Journal of Dairy Science, vol. 85, no. 4, pp. 721-729, 2002.

[42] R. J. Jones, H. M. Hussein, M. ZAgorec, G. Brightwell, and J. R. Tagg, "Isolation of lactic acid bacteria with inhibitory activity against pathogens and spoilage organisms associated with fresh meat," Food Microbiology, vol. 25, no. 2, pp. 228-234, 2008.

[43] K. Singhal, H. Joshi, and B. L. Chaudhary, "Bile and acid tolerance ability of probiotic Lactobacillus strains," Journal of Global Pharma Technology, vol. 2, pp. 17-25, 2010.

[44] C. Dunne, L. O’Mahony, L. Murphy et al., "In vitro selection criteria for probiotic bacteria of human origin: correlation with in vivo findings," The American Journal of Clinical Nutrition, vol. 73, no. 2, pp. 386s-392s, 2001.

[45] M. T. Liong and N. P. Shah, "Acid and bile tolerance and cholesterol removal ability of lactobacilli strains," Journal of Dairy Science, vol. 88, no. 1, pp. 55-66, 2005.

[46] B. Rohrig, "24 hours: your food on the move! chemmatters," 2012, https://www.acs.org/content/dam/acsorg/education/ resources/highschool/chemmatters/videos/chemmatters-feb2012digestion.pdf. 
[47] S. M. Barman, S. Boitano, and H. Brooks, Ganong's review of medical physiology, McGraw-Hill Publishing, New York, NY, USA, 2009.

[48] B. M. Corcoran, C. Stanton, G. F. Fitzgerald, and R. P. Ross, "Survival of probiotic Lactobacilli in acidic environments Is enhanced in the presence of metabolizable sugars," Applied and Environmental Microbiology, vol. 71, no. 6, pp. 30603067, 2005.

[49] M. E. Sanders, "Probiotics: definition, sources, selection, and uses," Clinical Infectious Diseases, vol. 46, no. 2, pp. S58-S61, 2008.

[50] Y.-K. Lee and S. Salminen, "The coming of age of probiotics," Trends in Food Science \& Technology, vol. 6, no. 7, pp. 241245, 1995.

[51] L. Fontana, M. Bermudez-Brito, J. Plaza-Diaz, S. MuñozQuezada, and A. Gil, "Sources, isolation, characterisation and evaluation of probiotics," British Journal of Nutrition, vol. 109, no. 2, pp. S35-S50, 2013.

[52] W. Liu, M. Chen, L. Duo et al., "Characterization of potentially probiotic lactic acid bacteria and bifidobacteria isolated from human colostrum," Journal of Dairy Science, vol. 103, no. 5, pp. 4013-4025, 2020.

[53] V. Gotcheva, E. Hristozova, T. Hristozova, M. Guo, Z. Roshkova, and A. Angelov, "Assessment of potential probiotic properties of lactic acid bacteria and yeast strains," Food Biotechnology, vol. 16, no. 3, pp. 211-225, 2002.

[54] N. Jose, C. Bunt, and M. Hussain, "Comparison of microbiological and probiotic characteristics of lactobacilli isolates from dairy food products and animal rumen contents," Microorganisms, vol. 3, no. 2, pp. 198-212, 2015.

[55] B. R. Goldin and S. L. Gorbach, "Probiotics for humans," in Probiotics, the Scientific Basis, R. Fuller, Ed., pp. 355-376, Chapman \& Hall, London, UK, 1992.

[56] R. H. Bassyouni, W. S. Abdel-All, M. G. Fadl, S. Abdel-All, and Z. Kamel, "Characterization of lactic acid bacteria isolated from dairy products in Egypt as a probiotic," Life Science Journal, vol. 9, pp. 2924-2933, 2012.

[57] A. Abushelaibi, S. Al-Mahadin, K. El-Tarabily, N. P. Shah, and M. Ayyash, "Characterization of potential probiotic lactic acid bacteria isolated from camel milk," LWT-Food Science and Technology, vol. 79, pp. 316-325, 2017.

[58] R. S. Kumar, J. A. Prabhune, A. A. Pundle et al., "Structural and functional analysis of a conjugated bile salt hydrolase from Bifidobacterium longum Reveals an evolutionary relationship with penicillin V acylase," Journal of Biological Chemistry, vol. 281, no. 43, pp. 32516-32525, 2006.

[59] D. Mohanty and P. Ray, "Evaluation of probiotic and antimicrobial properties of lactobacillus strains isolated from dairy products," International Journal of Pharmacy and Pharmaceutical Sciences, vol. 8, no. 11, pp. 230-234, 2016.

[60] S. Oh, S. H. Kim, and R. W. Worobo, "Characterization and purification of a bacteriocin produced by a potential probiotic culture, Lactobacillus acidophilus 30SC," Journal of Dairy Science, vol. 83, no. 12, pp. 2747-2752, 2000.

[61] M. Bermudez-brito, J. Plaza-Díaz, S. Muñoz-Quezada, C. Gómez-Llorente, and A. Gil, "Probiotic mechanisms of action," Annals of Nutrition and Metabolism, vol. 61, no. 2, pp. 160-174, 2012.

[62] R. Yadav, A. K. Puniya, and P. Shukla, "Probiotic properties of Lactobacillus plantarum RYPR1 from an indigenous fermented beverage Raabadi," Frontiers in Microbiology, vol. 7, p. 1683, 2016.

[63] M. Saarela, G. Mogensen, R. Fondén, J. Mättö, and T. Mattila-Sandholm, "Probiotic bacteria: safety, functional and technological properties," Journal of Biotechnology, vol. 84, no. 3, pp. 197-215, 2000.

[64] S. Mathur and R. Singh, "Antibiotic resistance in food lactic acid bacteria-a review," International Journal of Food Microbiology, vol. 105, no. 3, pp. 281-295, 2005.

[65] E. Broaders, C. G. M. Gahan, and J. R. Marchesi, "Mobile genetic elements of the human gastrointestinal tract," Gut Microbes, vol. 4, no. 4, pp. 271-280, 2013.

[66] M. Danielsen and A. Wind, "Susceptibility of Lactobacillus spp. to antimicrobial agents," International Journal of Food Microbiology, vol. 82, no. 1, pp. 1-11, 2003.

[67] G. Klein, A. Pack, C. Bonaparte, and G. Reuter, "Taxonomy and physiology of probiotic lactic acid bacteria," International Journal of Food Microbiology, vol. 41, no. 2, pp. 103125, 1998.

[68] M. S. Ammor, A. Belén Flórez, and B. Mayo, "Antibiotic resistance in non-enterococcal lactic acid bacteria and bifidobacteria," Food Microbiology, vol. 24, no. 6, pp. 559-570, 2007.

[69] J. S. Zhou, K. J. Rutherfurd, and H. S. Gill, "Inability of probiotic bacterial strains Lactobacillus rhamnosus HN001 and Bifidobacterium lactis HN019 to induce human platelet aggregation in vitro," Journal of Food Protection, vol. 68, no. 11, pp. 2459-2464, 2005.

[70] A. M. O. Leite, M. A. L. Miguel, R. S. Peixoto et al., "Probiotic potential of selected lactic acid bacteria strains isolated from Brazilian kefir grains," Journal of Dairy Science, vol. 98, no. 6, pp. 3622-3632, 2015.

[71] A. S. Hummel, C. Hertel, W. H. Holzapfel, and C. M. A. P. Franz, "Antibiotic resistances of starter and probiotic strains of lactic acid bacteria," Applied and Environmental Microbiology, vol. 73, no. 3, pp. 730-739, 2007.

[72] K. Kamboj, A. Vasquez, and J.-M. Balada-Llasat, "Identification and significance of Weissella species infections," Frontiers in Microbiology, vol. 6, p. 1204, 2015.

[73] K. Bacha, T. Mehari, and M. Ashenafi, "Antimicrobial susceptibility patterns of lab isolated from Wakalim, a traditional Ethiopian fermented sausage," Journal of Food Safety, vol. 30, no. 1, pp. 213-223, 2010.

[74] G. Spano, P. Russo, A. Lonvaud-Funel et al., "Biogenic amines in fermented foods," European Journal of Clinical Nutrition, vol. 64, no. 3, pp. S95-S100, 2010.

[75] M. P. Costa, B. L. Rodrigues, B. S. Frasao, and C. A. ConteJunior, "Biogenic amines as food quality index and chemical risk for human consumption," Food Quality: Balancing Health and Disease, vol. 13, pp. 75-108, 2018.

[76] F. Galgano, M. Caruso, N. Condelli, and F. Favati, "Focused review: agmatine in fermented foods," Frontiers in Microbiology, vol. 3, p. 199, 2012.

[77] V. L. Silva, C. A. Lázaro, E. Teixeira, S. B. Mano, and C. A. Conte-Junior, "Aminas biogênicas como indicadoresde qualidade de salames e produtos cárneos fermentados," Enciclopédia Biosfera, vol. 9, pp. 69-84, 2013.

[78] M. Schirone, R. Tofalo, G. Mazzone, A. Corsetti, and G. Suzzi, "Biogenic amine content and microbiological profile of Pecorino di Farindola cheese," Food Microbiology, vol. 28, no. 1, pp. 128-136, 2011.

[79] W. M. D. Priyadarshani and S. K. Rakshit, "Screening selected strains of probiotic lactic acid bacteria for their ability to produce biogenic amines (histamine and tyramine)," International Journal of Food Science \& Technology, vol. 46, pp. 2062-2069, 2011

[80] S. Bover-Cid and W. H. Holzapfel, "Improved screening procedure for biogenic amine production by lactic acid 
bacteria," International Journal of Food Microbiology, vol. 53, no. 1, pp. 33-41, 1999.

[81] J. M. Landete, I. Pardo, and S. Ferrer, "Tyramine and phenylethylamine production among lactic acid bacteria isolated from wine," International Journal of Food Microbiology, vol. 115, no. 3, pp. 364-368, 2007.

[82] M. Derrien, E. E. Vaughan, C. M. Plugge, and W. M. De Vos, "Akkermansia muciniphila gen. nov., sp. nov., a human intestinal mucin-degrading bacterium," International Journal of Systematic and Evolutionary Microbiology, vol. 54, no. 5, pp. 1469-1476, 2004.

[83] J. S. Zhou, P. K. Gopal, and H. S. Gill, "Potential probiotic lactic acid bacteria Lactobacillus rhamnosus (HN001), Lactobacillus acidophilus (HN017) and Bifidobacterium lactis (HN019) do not degrade gastric mucin in vitro," International Journal of Food Microbiology, vol. 63, no. 1-2, pp. 81-90, 2001.

[84] L. C. Hoskins and E. T. Boulding, "Mucin degradation in human colon ecosystems," Journal of Clinical Investigation, vol. 67 , no. 1, pp. 163-172, 1981.

[85] E. Pessione, "Lactic acid bacteria contribution to gut microbiota complexity: lights and shadows," Frontiers in Cellular and Infection Microbiology, vol. 2, pp. 1-15, 2012.

[86] G. T. Macfarlane and G. R. Gibson, "Formation of glycoprotein degrading enzymes byBacteroides fragilis," FEMS Microbiology Letters, vol. 77, no. 2-3, pp. 289-294, 1991.

[87] B. Deplancke, O. Vidal, D. Ganessunker, S. M. Donovan, R. I. Mackie, and H. R. Gaskins, "Selective growth of mucolytic bacteria including Clostridium perfringens in a neonatal piglet model of total parenteral nutrition," The American Journal of Clinical Nutrition, vol. 76, no. 5, pp. 1117-1125, 2002.

[88] P. Ruas-Madiedo, M. Gueimonde, M. Fernández-García, C. G. de los Reyes-Gavilán, and A. Margolles, "Mucin degradation by Bifidobacterium strains isolated from the human intestinal microbiota," Applied and Environmental Microbiology, vol. 74, no. 6, pp. 1936-1940, 2008.

[89] D. C. Donohue, "Safety of probiotics," Asia Pacific Journal of Clinical Nutrition, vol. 15, no. 4, pp. 563-569, 2006.

[90] M. F. Fernández, S. Boris, and C. Barbés, "Safety evaluation of Lactobacillus delbrueckii subsp. lactis UO 004, a probiotic bacterium," Research in Microbiology, vol. 156, no. 2, pp. 154-160, 2005.

[91] M. A. García, M. L. Marina, A. Ríos, and M. Valcárcel, "Separation modes in capillary electrophoresis," in Analysis and Detection by Capillary Electrophoresis, Elsevier, Amsterdam, Netherlands, 2005.

[92] C. L. Grady Jr, G. T. Daigger, N. G. Love, and C. D. Filipe, Biological Wastewater Treatment, CRC Press, Boca Raton, FL, USA, 2011.

[93] B. Del Re, B. Sgorbati, M. Miglioli, and D. Palenzona, "Adhesion, autoaggregation and hydrophobicity of 13 strains of Bifidobacterium longum," Letters in Applied Microbiology, vol. 31, no. 6, pp. 438-442, 2000.

[94] M. C. Collado, J. Meriluoto, and S. Salminen, "Role of commercial probiotic strains against human pathogen adhesion to intestinal mucus," Letters in Applied Microbiology, vol. 45, no. 4, pp. 454-460, 2007.

[95] L. R. Rodrigues, "Inhibition of bacterial adhesion on medical devices," Bacterial Adhesion, pp. 351-367, Springer, Dordrecht, Netherlands, 2011.

[96] T. Padmavathi, R. Bhargavi, P. R. Priyanka, N. R. Niranjan, and P. V. Pavitra, "Screening of potential probiotic lactic acid bacteria and production of amylase and its partial purification," Journal of Genetic Engineering and Biotechnology, vol. 16, no. 2, pp. 357-362, 2018.

[97] M. Zago, M. E. Fornasari, D. Carminati et al., "Characterization and probiotic potential of Lactobacillus plantarum strains isolated from cheeses," Food Microbiology, vol. 28, no. 5, pp. 1033-1040, 2011.

[98] J. K. Kaushik, A. Kumar, R. K. Duary, A. K. Mohanty, S. Grover, and V. K. Batish, "Functional and probiotic attributes of an indigenous isolate of Lactobacillus plantarum," PLoS One, vol. 4, no. 12, p. e8099, 2009.

[99] R. Dowarah, A. K. Verma, N. Agarwal, P. Singh, and B. R. Singh, "Selection and characterization of probiotic lactic acid bacteria and its impact on growth, nutrient digestibility, health and antioxidant status in weaned piglets," PLoS One, vol. 13, no. 3, Article ID e0192978, 2018.

[100] T. Dhewa, S. Pant, N. Goyal, and V. Mishra, "Adhesive properties of food and faecal potential probiotic lactobacilli," Journal of Applied and Natural Science, vol. 1, no. 2, pp. 138-140, 2009.

[101] M. S. Juarez Tomas, B. Wiese, and M. E. Nader-Macias, "Effects of culture conditions on the growth and auto-aggregation ability of vaginal Lactobacillus johnsonii CRL 1294," Journal of Applied Microbiology, vol. 99, no. 6, pp. 1383-1391, 2005.

[102] M. C. De Vries, E. E. Vaughan, M. Kleerebezem, and W. M. De Vos, "Lactobacillus plantarum-survival, functional and potential probiotic properties in the human intestinal tract," International Dairy Journal, vol. 16, no. 9, pp. 1018-1028, 2006.

[103] K. Ramiah, C. A. Van Reenen, and L. M. T. Dicks, "Expression of the mucus adhesion genes $M u b$ and MapA, adhesion-like factor EF-Tu and bacteriocin gene plaA of Lactobacillus plantarum 423, monitored with real-time PCR," International Journal of Food Microbiology, vol. 116, no. 3, pp. 405-409, 2007.

[104] C. Iñiguez-Palomares, R. Pérez-Morales, and E. Acedo-Félix, "Evaluation of probiotic properties in Lactobacillus isolated from small intestine of piglets," Revista Latinoamericana de Microbiología, vol. 49, pp. 46-54, 2007.

[105] B. Del Re, A. Busetto, G. Vignola, B. Sgorbati, and D. L. Palenzona, "Autoaggregation and adhesion ability in aBifidobacterium suisstrain," Letters in Applied Microbiology, vol. 27, no. 5, pp. 307-310, 1998.

[106] P. F. Pérez, Y. Minnaard, E. A. Disalvo, and G. L. De Antoni, "Surface properties of bifidobacterial strains of human origin," Applied and Environmental Microbiology, vol. 64, no. 1, pp. 21-26, 1998.

[107] M. C. Espeche, M. Pellegrino, I. Frola, A. Larriestra, C. Bogni, and M. F. Nader-Macías, "Lactic acid bacteria from raw milk as potentially beneficial strains to prevent bovine mastitis," Anaerobe, vol. 18, no. 1, pp. 103-109, 2012.

[108] H. Xu, H. S. Jeong, H. Y. Lee, and J. Ahn, "Assessment of cell surface properties and adhesion potential of selected probiotic strains," Letters in Applied Microbiology, vol. 49, no. 4, pp. 434-442, 2009.

[109] L.-S. Chou and B. Weimer, "Isolation and characterization of acid- and bile-tolerant isolates from strains of lactobacillus acidophilus," Journal of Dairy Science, vol. 82, no. 1, pp. 23-31, 1999.

[110] G. R. Veerappan, J. Betteridge, and P. E. Young, "Probiotics for the treatment of inflammatory bowel disease," Current Gastroenterology Reports, vol. 14, no. 4, pp. 324-333, 2012.

[111] D. R. Mack, S. Ahrne, L. Hyde, S. Wei, and M. A. Hollingsworth, "Extracellular MUC3 mucin secretion 
follows adherence of Lactobacillus strains to intestinal epithelial cells in vitro," Gut, vol. 52, no. 6, pp. 827-833, 2003.

[112] C. Caballero-Franco, K. Keller, C. De Simone, and K. Chadee, "The VSL\#3 probiotic formula induces mucin gene expression and secretion in colonic epithelial cells," American Journal of Physiology-Gastrointestinal and Liver Physiology, vol. 292, no. 1, pp. G315-G322, 2007.

[113] S. N. Ukena, A. Singh, U. Dringenberg et al., "Probiotic Escherichia coli Nissle 1917 inhibits leaky gut by enhancing mucosal integrity," PLoS One, vol. 2, no. 12, Article ID e1308, 2007.

[114] J. Karczewski, F. J. Troost, I. Konings et al., "Regulation of human epithelial tight junction proteins by Lactobacillus plantarum in vivo and protective effects on the epithelial barrier," American Journal of Physiology-Gastrointestinal and Liver Physiology, vol. 298, no. 6, pp. G851-G859, 2010.

[115] E. B. Minelli and A. Benini, "Relationship between number of bacteria and their probiotic effects," Microbial Ecology in Health and Disease, vol. 20, no. 4, pp. 180-183, 2008.

[116] M. Botes, C. A. Van Reenen, and L. M. T. Dicks, "Evaluation of Enterococcus mundtii ST4SA and Lactobacillus plantarum 423 as probiotics by using a gastro-intestinal model with infant milk formulations as substrate," International Journal of Food Microbiology, vol. 128, no. 2, pp. 362-370, 2008.

[117] S. Kaewnopparat, N. Dangmanee, N. Kaewnopparat, T. Srichana, M. Chulasiri, and S. Settharaksa, "In vitro probiotic properties of Lactobacillus fermentum SK5 isolated from vagina of a healthy woman," Anaerobe, vol. 22, pp. 6-13, 2013.

[118] Q. Li, X. Liu, M. Dong, J. Zhou, and Y. Wang, “Aggregation and adhesion abilities of 18 lactic acid bacteria strains isolated from traditional fermented food," International Journal of Agricultural Policy and Research, vol. 3, pp. 84-92, 2015.

[119] I. Arief, B. S. L. Jenie, M. Astawan, K. Fujiyama, and A. B. Witarto, "Identification and probiotic characteristics of lactic acid bacteria isolated from Indonesian local beef," Asian Journal of Animal Sciences, vol. 9, pp. 25-36, 2015.

[120] F. Armas, C. Camperio, and C. Marianelli, "In vitro assessment of the probiotic potential of Lactococcus lactis LMG 7930 against ruminant mastitis-causing pathogens," PLoS One, vol. 12, no. 1, Article ID e0169543, 2017.

[121] A. L. Servin, "Antagonistic activities of lactobacilli and bifidobacteria against microbial pathogens," FEMS Microbiology Reviews, vol. 28, no. 4, pp. 405-440, 2004.

[122] E. Z. Mirzaei, E. Lashani, and A. Davoodabadi, "Antimicrobial properties of lactic acid bacteria isolated from traditional yogurt and milk against Shigella strains," GMS Hyg Infect Control, vol. 13, pp. 1-5, 2018.

[123] H.-L. Alakomi, E. Skyttä, M. Saarela, T. Mattila-Sandholm, K. Latva-Kala, and I. M. Helander, "Lactic acid permeabilizes gram-negative bacteria by disrupting the outer membrane," Applied and Environmental Microbiology, vol. 66, no. 5, pp. 2001-2005, 2000.

[124] F. J. M. Smulders, P. Barendsen, J. G. Van Logtestijn, D. A. A. Mossel, and G. M. Van der Marel, "Review: lactic acid: considerations in favour of its acceptance as a meat decontamininant," International Journal of Food Science \& Technology, vol. 21, no. 4, pp. 419-436, 2007. 